\title{
Upokorzony i uwielbiony Chrystus (Flp 2, 6-11)
}

Flp 2, 6-11 jest uznawany jako hymn chrystologiczny ze względu na swą treść i poetycką formę literacką ${ }^{1}$. Znajduje się on w części listu 1, 27-2, 18 zawierającej zachęty skierowane do wspólnoty w Filippi. Tekst hymnu sam w sobie jest doktrynalny, umieszczony w kontekście życia codziennego chrześcijan, służy więc parenezie. W 2, 1-4 Paweł napomina Filipian, aby byli pokorni, oddający się służbie, pełni samozaparcia. Werset 5 dodatkowo wzmacnia to pouczenie, ukazując Chrystusa jako wzór postawy dla chrześcijan. Wersety zaś 6-11 opisują Go uniżonego, upokorzonego do granic możliwości i jednocześnie wywyższonego ponad wszystko. W 2, 3-

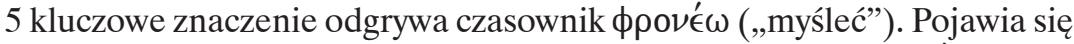

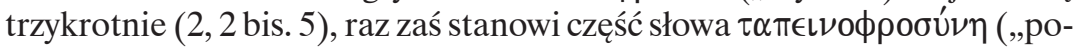
kora, skromność") $(2,3)$. Angażuje on całą osobę chrześcijanina: umysł, wolę, uczucia, warunkuje relacje międzyosobowe i określa egzystencjalną postawę wobec tego, co się w życiu wydarza²

W wersecie $5 \phi \rho 0 \nu ' \epsilon$ w wiąże zachętę z poprzednich wersetów z hymnem chrystologicznym i stanowi przejście z parenezy skierowanej do Kościoła w Filippi do przykładu Chrystusa ${ }^{3}$. To właśnie Jego sposób myślenia, postępowania, odczuwania ma być dla chrześcijanina normą i zasadą ${ }^{4}$.

${ }^{1}$ Por. J. Heriban, Inno cristologico (Flp 2, 6-11), [w:] Lettere Paoline e altre lettere, A. Sacchi e collaboratori, Torino 1995, 446. R. Penna uważa jednak, iż termin hymn w odniesieniu do Flp 2, 6-11 nie brzmi adekwatnie, ponieważ nie jest kompozycją poetycką odpowiadającą normom klasycznym. W nazwie „hymn” dostrzega wartość ogólną pieśni celebrowanej na cześć Chrystusa. Ma też świadomość, że ze starożytności dochowały się przykłady hymnów będących uwielbieniem jakiejś boskiej osoby poprzez wyliczanie jej czynów. Dostrzega w tym tło dla naszego tekstu - por. R. Penna, Lettera ai Filippesi, Lettera a Filemone, Roma 2002, s. 45.

${ }^{2}$ Por. J. Heriban, Inno cristologico (Flp 2, 6-11), art. cyt., 382. Czasownik ten wiąże się z rzeczownikiem $\phi \rho \eta \dot{\nu}$ („myśl”), który wyraża psychosomatyczną jedność człowieka - por.

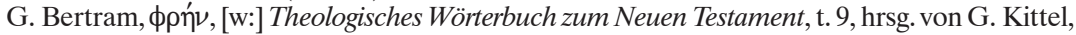
G. Friedrich, Stuttgart 1974, 217.

${ }^{3}$ Por. D. J. MacLeod, Imitating the incarnation of Christ: An exposition of Philippians 2: 5-8, „Bibliotheca Sacra” 158 (2001), 310.

${ }^{4}$ Paweł, umieszczając hymn w liście, nie zamierzał przekazać syntezy teologiczno-doktrynalnej dotyczącej osoby Chrystusa (Jego preegzystencji, wcielenia, dwóch natur itd.), lecz 
W hymnie możemy wyróżnić dwie części. Pierwsza obejmuje wersety 6-8 opisujące uniżenie Jezusa, druga natomiast ogarnia wersety 9-11 podkreślające Jego wywyższenie. Wiążą się one ze sobą poprzez oı́ k $\alpha \grave{\imath}$ (,i dlatego" $)^{5}$. Dostrzegamy w nich nie tylko kontrast tematyczny, lecz także różne podmioty. W pierwszej części jest nim Jezus Chrystus przywołany przez zaimek względny „który”, w drugiej zaś - Bóg.

Hymn nie jest jednak dziełem Pawła. Istniał bowiem wcześniej zanim został redakcyjnie umieszczony w liście ${ }^{6}$. Jego tekst zachowuje swą oryginalność, chociaż mogły na niego wpłynąć motywy różnego pochodzenia ${ }^{7}$.

\section{Uniżenie Jezusa (wersy 6-8)}

Hymn otwiera się zaimkiem względnym ő $\varsigma$ w odniesieniu do Jezusa, o którym traktuje zakończenie poprzedzającej zachęty $(2,5 b)$. Tekst pod-

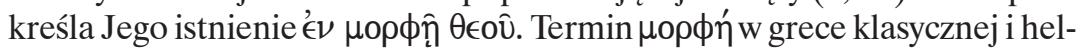
lenistycznej oznacza: „postać, cielesne ukazanie się dające się spostrzec

pragnął zaproponować chrześcijanom pokorną postawę Chrystusa jako przykład dla ich wspólnego życia - por. J. Heriban, Inno cristologico (Flp 2, 6-11), art. cyt., 387.

${ }^{5}$ Por. G. Barbaglio, La Teologia di Paolo, Bologna 20012, 359. Autor powołuje się na: J. Jeremias, Zu Phil II, 7, „Novum Testamentum” 6 (1963), 182-188, i zaznacza, że jest możliwy także trójczłonowy podział: 6-7a - preegzystencja; 7b-8 - życie ziemskie; 9-11 - życie niebiańskie.

${ }^{6}$ Por. J. Ernst, Die Briefe an die Philipper, an Philemon, an die Kolosser, an die Epheser, Regensburg 1974, 66. Są wyraźne powody, aby uznać, iż hymn nie wyszedł spod pióra Pawła, tylko został przez niego przejęty. Wystarczy zauważyć, iż wzmianka o śmierci Jezusa na krzyżu (w. 8) nie odgrywa centralnej roli. Ma czystą wartość moralnego przykładu, by maksymalnie uwydatnić wartość posłuszeństwa. To zaś kontrastuje z normalnym tokiem myśli Pawła, który śmierć Chrystusa łączy z wymiarem soteriologicznym (por. Rz 4, 25; 5, 6-8; 1 Kor 15, 3) albo z tematem uczestnictwa w niej: apostoła (por. 2 Kor 4, 10; 13, 3-4), ochrzczonego (por. Rz 6, 3) - por. R. Penna, Lettera ai Filippesi, Lettera a Filemone, dz. cyt., 45. Nadto chrystologiczny schemat: śmierć - zmartwychwstanie jest zastąpiony przez trójczłonowy model: preegzystencja - uniżenie - wywyższenie - por. J. Ernst, Die Briefe an die Philipper, an Philemon, an die Kolosser, an die Epheser, dz. cyt., 66. Poza tym ogólna semantyka fragmentu przewyższa semantykę kontekstu. Rzeczywiście tylko wersety 6-8 mają prawdziwą funkcję kontekstualną. Służą jako fundament, by unikać wszelkiej próżnej chwały i wybierać pokorę we wzajemnych relacjach. Natomiast wersety 9-11 nie mają bezpośredniego związku z kontekstem. Ich celem nie jest potwierdzenie ewangelicznej zasady: kto się poniża, będzie wywyższony $($ Łk 14, 11). Mamy więc do czynienia z kompozycją, która została w całości przejęta i umieszczona w tekście - por. R. Penna, Lettera ai Filippesi, Lettera a Filemone, dz. cyt., 47.

${ }^{7}$ Por. tamże. Pewną analogię z hymnem można dostrzec w czwartej pieśni cierpiącego Sługi Jahwe (Iz 53). Mówi bowiem o Jego uniżeniu i wywyższeniu. Jednak nie ma w niej idei preegzystencji, która wyróżnia Flp 2, 6-11. Z kolei w hymnie brak tematu zastępczej ekspiacji typowej dla tekstu Izajaszowego. Być może inspiracją dla Flp 2, 6-11 był tekst z tradycji mądrościowej traktujący o uosobionej Mądrości preegzystującej u Boga (por. Prz 8, 22-31). Jednak nie spotykamy tam żadnej wzmianki o jej śmierci i zmartwychwstaniu - por. tamże. 
zmysłami, wdzięk, wygląd"•. Również w LXX wskazuje na czyjś wygląd (por. Sdz 8, 18; Hi 4, 16; Dn 3, 19), widzialną postać (por. Iz 44, 13). W Flp 2, 6 pojęcie to zostało zinterpretowane jako odpowiednik terminów za-

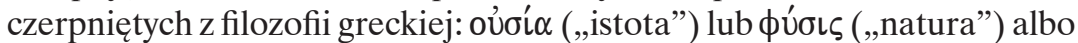

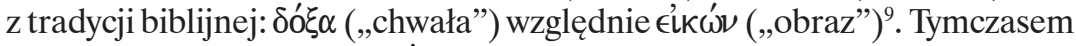
prawdziwe znaczenie $\mu$ o $\phi \eta ́$ w Flp 2, 6 można wydobyć, mając na uwadze,

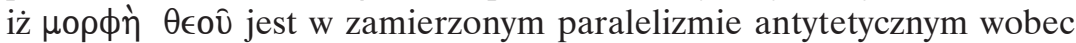

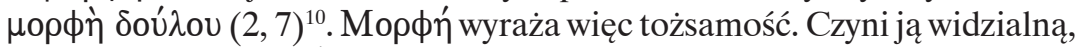

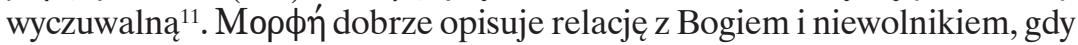

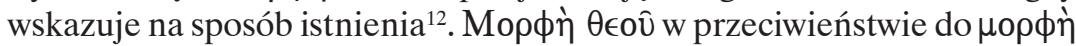

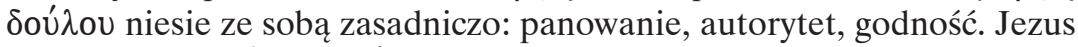

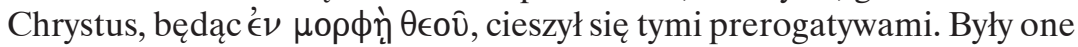
Jego naturalnym przywilejem ${ }^{13}$. Jednak cały akcent spoczywa na drugiej

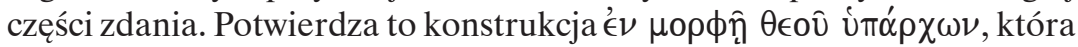
ma walor zdania przyzwalającego - „chociaż będąc w sposobie istnienia Boga"14. Boży sposób istnienia Jezusa Chrystusa jest tylko punktem wyjścia, by podkreślić to, co następuje. W dalszej części wersetu 6 pojawia się enigmatyczny, bardzo dyskutowany termin $\alpha \rho \pi \alpha \gamma \mu$ ós. Poza Flp 2, 6b rzadko pojawia się on w literaturze chrześcijańskiej ${ }^{15}$. Może być rozumiany w sensie aktywnym - coś do porwania lub pasywnym - coś do zachowania. W kontekście 2, 6 obydwa znaczenia rodzą trudności. Jak Chrystus, będąc w sposobie istnienia Boga może uznać za przedmiot porwania

${ }^{8}$ Por. W. Pöhlmann, $\mu \rho \rho \phi \eta ́$, [w:] Exegetisches Wörterbuch zum Neuen Testament, hrsg. von H. Balz, G. Schneider, t. 2, Stuttgart 1992, 1089.

${ }^{9}$ Por. J. Heriban, Inno cristologico (Flp 2, 6-11), art. cyt., 387.

${ }^{10}$ Por. tamże.

${ }^{11}$ Por. R. Fabris, Lettera ai Filippesi, Lettera a Filemone, Bologna 2001, 127. Przyimek év

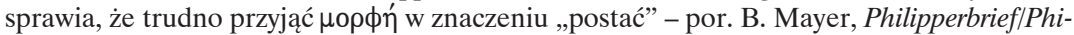
lemonbrief, Stuttgart 1986, 28.

${ }^{12}$ Por. J. Gnilka, Der Philipperbrief/Der Philemonbrief, Freiburg-Basel-Wien 2000²3, 114. Autor wyklucza znaczenie $\mu$ орфүं w sensie ,postać, pozycja czy status”. S. Légasse dostrzega w tym trudnym do oddania terminie: „rysy, kontur” - por. S. Légasse, L'epître aux Philippiens, L'epître á Philemon, „Les Cahiers Évangile” 33 (1980), 25. S. Mędala tłumaczy $\mu$ opфń jako „rysy, kondycja, pozycja” - por. S. Mędala, Świadectwo mocy Chrystusa (List do Filipian), [w:] Wprowadzenie w myśl $i$ wezwanie Ksiag biblijnych (9). Dzieje Apostolskie, Listy św. Pawła, Warszawa 1997, 395.

${ }^{13}$ Por. J. Heriban, Inno cristologico (Flp 2, 6-11), art. cyt., 388.

${ }^{14} \mathrm{Z}$ gramatycznego punktu widzenia wymieniona powyżej konstrukcja pozwala także na inne przekłady: „ponieważ był w sposobie istnienia Boga”; „gdy był...”- por. R. Fabris, Lettera ai Filippesi, Lettera a Filemone, dz. cyt., 128. Za znaczeniem: „ponieważ był...” opowiada się D. J. MacLeod, Imitating the incarnation of Christ..., art. cyt., 317.

${ }^{15}$ Por. J. Heriban, Inno cristologico (Flp 2, 6-11), art. cyt., 388. 
lub zatrzymania bycie na równi z Bogiem? ${ }^{16}$. Rozwiązanie tej kwestii

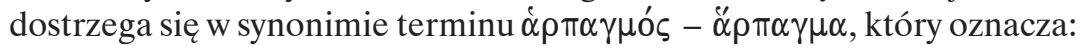
„rzecz znaleziona przypadkiem, szczęśliwy dar”. Połączenie zaś czasow-

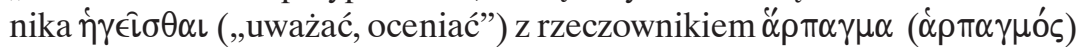
stanowi idiom: „uznać coś jako okazję i wyciągnąć z niej korzyść”"17. Interpretacja idiomatyczna dobrze harmonizuje z kontekstem 2, 6. Całe zdanie można by sparafrazować tak: Chrystus Jezus, który od zawsze

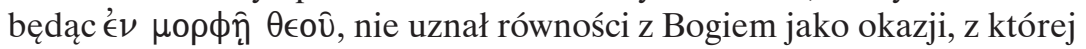
mógłby wyciągnąć dla siebie korzyść. Zdanie „być na równi z Bogiem” współbrzmi więc $\mathrm{z}$ byciem w Bożym sposobie istnienia ${ }^{18}$. Rzeczywiście

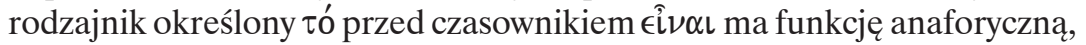
tzn. odsyła do tego, co zostało wypowiedziane wcześniej ${ }^{19}$. Również wybór

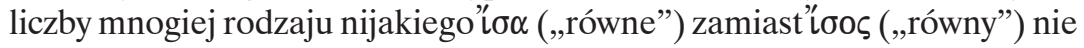
jest przypadkowy, kładzie bowiem nacisk na tożsamość typu relacyjnego, równość godności ${ }^{20}$. Życie na równi z Bogiem wiąże się z godnością, władzą. Chrystus nie uznał ich jako korzyści dla siebie. Nie oczekiwał, by ludzie Go respektowali, okazywali cześć i posłuszeństwo ${ }^{21}$. Wybrał bowiem drogę ogołocenia. Podkreśla ją przeciwstawna partykuła $\alpha \lambda \lambda \alpha^{\prime}$ (w. 7), która kładzie nacisk na akt zupełnie nieoczekiwany, sensacyjny. Wprowadza fundamentalne stwierdzenie, które rządzi wszystkim, co nastąpi później

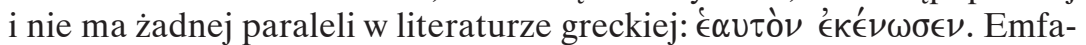
tyczna pozycja zaimka є̇ $\alpha u \tau o ́ \nu$ akcentuje, iż czynność Chrystusa opisana

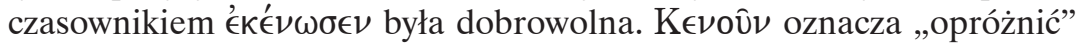
i wskazuje na wyrzeczenie się tego, co było wcześniej ${ }^{22}$. Chrystus zatem dobrowolnie „opróżnił samego siebie"23. Zdanie to ma wydźwięk meta-

${ }^{16}$ Por. R. Fabris, Lettera ai Filippesi, Lettera a Filemone, dz. cyt., 129.

${ }^{17}$ Por. tamże.

${ }^{18}$ Por. tamże.

${ }^{19}$ Por. F. Blass, A. Debrunner, F. Rehkopf, Grammatik des neutestamentlichen Griechisch, Göttingen $1984^{16}$, par. 398.

${ }^{20}$ Por. R. Fabris, Lettera ai Filippesi, Lettera a Filemone, dz. cyt., 129, przypis 56. Wyrażenie 'øos $\theta \in \hat{\omega}$ podkreślałoby natomiast identyczność natury, bycie takim samym jak Bóg.

${ }^{21}$ Por. J. Heriban, Inno cristologico (Flp 2, 6-11), art. cyt., 388.

${ }^{22}$ Por. R. Penna, Lettera ai Filippesi, Lettera a Filemone, dz. cyt., 49.

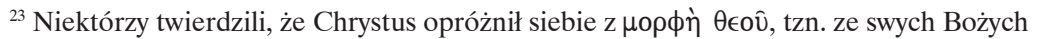
atrybutów. Był to pogląd dziewiętnastowiecznych szwedzkich luterańskich uczonych znanych jako kenotyczni teolodzy. Jednak ich przekonania sprzeciwiają się egzegezie i logice.

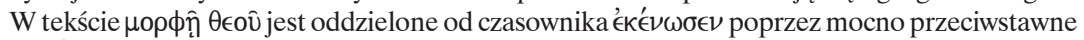
$\dot{\alpha} \lambda \lambda \dot{\alpha}$ (,lecz”), dlatego też z punktu widzenia gramatyki okazuje się niemożliwe, żeby $\mu$ opфñ

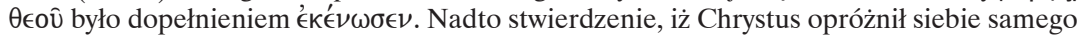
z Bożych atrybutów, oznaczałoby, że przestał być Bogiem - por. D. J. MacLeod, Imitating the incarnation of Christ..., art. cyt., 317. 
foryczny ${ }^{24}$ i należy je rozumieć: „,ogołocił siebie samego”, czyli ukrył swój Boży sposób istnienia ${ }^{25}$. Zamienił go na nieskończenie niższy i uboższy. Chrystus przyjął coś, czego nie miał, czyli sposób istnienia niewolnika

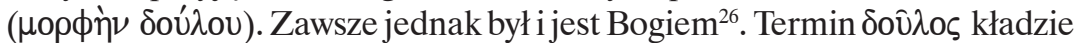
nacisk, że wszedł On w strumień życia jako niewolnik, czyli osoba bez praw, przywilejów, pozbawiona godności, autorytetu, całkowicie oddana pokornej służbie drugim ${ }^{27}$. Chrystus uczynił się także solidarnym z całym rodzajem ludzkim. Pojęcie ó $\mu$ oí $\omega \mu \alpha$ z jednej strony może wskazywać na identyczność, podkreślając identyczny duplikat oryginału ${ }^{28}$, z drugiej zaś sugeruje podobieństwo, które implikuje pewną różnicę. Wyrażenie więc

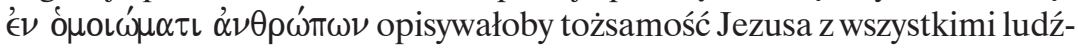
mi lub Jego podobieństwo z wykluczeniem grzechu. Wprawdzie w Rz 8, 3 ó $\mu o^{\prime} \omega \mu \alpha$ w kontekście wcielenia zaznacza różnicę między Chrystusem a grzesznymi ludźmi, to jednak w Flp 2, 6-11 sytuacja jest inna. Grzech nie jest punktem wyjścia dla hymnu ${ }^{29}$ ani się w nim nie pojawia. Zatem

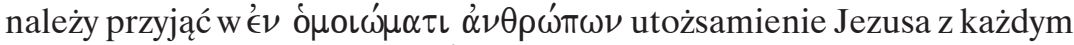
człowiekiem. Imiesłów zaś $\gamma \in \nu$ ó $\mu \in \nu$ os (,stawszy się”), podobnie jak wcześniej $\lambda \alpha \dot{\beta} \omega \nu$ (,przyjąwszy”), wyraża dynamizm wyboru Jezusa i przywołuje w pismach Pawła niektóre formuły wiary związane z Jego historyczną i antropologiczną kondycją (por. Rz 1, 3; Ga 4, 4-5) ${ }^{30}$.

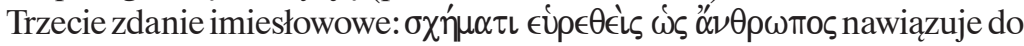
dwóch poprzednich i stanowi sentencję konkluzywną: Jezus był rozpoznawany jako człowiek. Hymn stwierdza realizm Jego człowieczeństwa. Słowo $\sigma \chi \hat{\eta} \mu \alpha$ w grece klasycznej zawsze opisuje postać lub strukturę postrzegane od zewnątrz przez zmysły; podkreśla to, co zewnętrznie można zobaczyć,

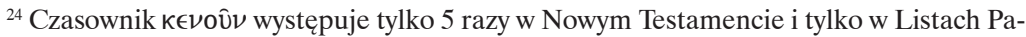
włowych. Czterokrotnie ma sens metaforyczny. Opisuje pustą wiarę (por. Rz 4, 14), daremną chlubę (por. 2 Kor 9,3), pojawia się w kontekście troski o krzyż, by go nie zniweczyć, oraz ma znaczenie „pozbawić” w odniesieniu do chluby (1 Kor 9, 15). Należy się więc spodziewać, iż podobny, metaforyczny sens jest także w Flp 2, 7.

${ }^{25}$ Por. R. Penna, Lettera ai Filippesi, Lettera a Filemone, dz. cyt., 48.

${ }^{26}$ Chrystus, przyjmując $\mu$ офф́n niewolnika, nie przestał być Bogiem, jak to podkreślałwerset $6 \mathrm{w}$ imiesłowie úmá $\rho \chi \omega \nu$ (,istniejąc”). Sposób istnienia Chrystusa może być zamieniony na inny (por. 2 Kor 8, 9), jednak zawsze pozostaje tą samą osobą (por. D. J. MacLeod, Imitating the incarnation of Christ..., art. cyt., 320).

${ }^{27}$ Najlepszym komentarzem ewangelicznym do Flp 2, 6-7 jest bez wątpienia Janowa scena umycia nóg (J 13, 1-16) - por. J. Heriban, Inno cristologico (Flp 2, 6-11), art. cyt., 389, przyp. 24.

${ }^{28}$ Por. P. T. O'Brien, The Epistle to the Philippians. A Commentary on the Greek Text, Grand Rapids 1991, 225.

${ }^{29}$ Por. tamże.

${ }^{30}$ Por. R. Fabris, Lettera ai Filippesi, Lettera a Filemone, dz. cyt., 132. 
stwierdzić31, poddać kontroli32 ${ }^{32}$ Człowieczeństwo Jezusa było dla ludzi czymś

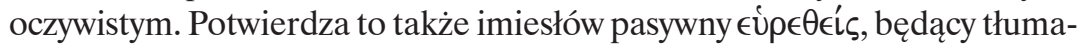
czeniem hebrajskiego נִמְָּא (nimca), które przywołuje łatwość poznania, doświadczenia, udowodnienia ${ }^{33}$. Także przysłówek względny $\omega \varsigma$ nie sugeruje w naszym kontekście porównania, raczej wprowadza charakterystyczną jakość ${ }^{34}$. W Flp 2, 7 dotyczy ona Jezusowego człowieczeństwa.

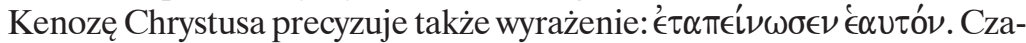
sownik $\tau \alpha \pi \epsilon L \nu 0 \hat{\nu}$ („,uniżyć się, upokorzyć”) stanowi w Nowym Testamencie przeciwieństwo do odczuć związanych z próżnością, ambicjami i samowywyższeniem (por. Mt 18, 4; 23, 12; Łk 14, 11; 18, 14). Samoupokorzenie Jezusa wyraża się więc w przyjęciu stałego uniżania się, któremu obce jest zwracanie na siebie uwagi. Dobrowolne upokorzenie się Chrystusa podkreśla

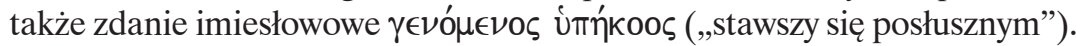
Wzmianka o posłuszeństwie jest ujęta w formie absolutnej. Tekst nie precyzuje bezpośrednio, komu Chrystus okazał posłuszeństwo ${ }^{35}$. Cała uwaga koncentruje się na posłuszeństwie samym w sobie jako absolutnej wartości w życiu Chrystusa ${ }^{36}$. Było ono widoczne w całej Jego postawie aż do śmier-

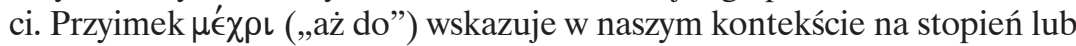
miarę ${ }^{37}$. Opisuje zatem posłuszeństwo, które nie ustępuje w obliczu żadnej osobistej ofiary, nawet najwyższej, czyli z własnego życia ${ }^{38}$. Podwójne $\theta \alpha \dot{\nu} \alpha \tau$ ఒo akcentuje niezwykły rodzaj śmierci Chrystusa. Nie była to zwyczajna śmierć, lecz krzyżowa. Jej haniebny charakter podkreśla brak rodzajnika przed słowem $\sigma \tau \alpha u p o ́ \varsigma$ („krzyż”). Już samo to pojęcie było formą zniewagi funkcjonującą w języku niewolników i prostytutek ${ }^{39}$. Istniało powiedzenie „, in malam maximam crucem”, które oznaczało mniej więcej „idź do diabła” ${ }^{40}$.

${ }^{31}$ Por. J. Schneider, $\sigma \chi \hat{\eta} \mu \alpha$, [w:] Theologisches Wörterbuch zum Neuen Testament, t. 7, hrsg. von G. Friedrich, Stuttgart 1966, 954.

${ }^{32}$ Por. J. Gnilka, Der Philipperbrief/Der Philemonbrief, dz. cyt., 121.

${ }^{33}$ Por. tamże.

${ }^{34}$ Por. W. Bauer, $\omega \varsigma$, [w:] Wörterbuch zum Neuen Testament, Berlin-New York 19716, 1774, III, 1.

${ }^{35}$ Flp 2, 9 jasno wskazuje, że Chrystus był posłuszny Ojcu (por. J 6, 38; 8, 29; 14, 31; 15, 10; $\operatorname{Hbr} 10,7)$.

${ }^{36}$ Por. R. Penna, Lettera ai Filippesi, Lettera a Filemone, dz. cyt., 51.

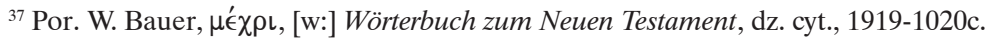

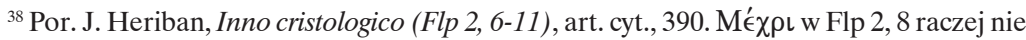
jest użyte w sensie chronologicznym - aż po ostatnie tchnienie - por. tamże.

${ }^{39}$ Por. M. Hengel, La crucifixion dans l'antiquité et la folie du message de la croix, Paris 1981, 22-23.

${ }^{40}$ Tamże 23. W kulturalnym rzymskim społeczeństwie słowo krzyż było obsceniczne, nie należało go używać w konwersacjach - por. P. T. O'Brien, The Epistle to the Philippians..., dz. cyt., 231. 
Śmierć krzyżową uważano za najokrutniejszą i najbardziej bolesną. W środowisku rzymskim jej następstwem była damnatio ad bestias ${ }^{41}$. Wymierzano ją najgorszym zbrodniarzom, więźniom wojennym oraz niewolnikom ${ }^{42}$, czyli ludziom, z którymi nikt się nie liczył ${ }^{43}$. Śmierć przez ukrzyżowanie wykonywano publicznie w znaczącym miejscu, by skutecznie wywołać zastraszenie ${ }^{44}$. Poprzedzały ją inne formy tortur łącznie z chłostą. Winowajca mógł być przez szereg dni dręczony w sposób trudny do wyobrażenia ${ }^{45}$. W hymnie śmierć krzyżowa Chrystusa stanowi szczyt upokorzenia, najniższy stopień Jego zstępowania w dół.

\section{Wywyższenie Jezusa (wersy 9-11)}

Pełne posłuszeństwa uniżenie oraz wywyższenie nie są rzeczywistościami niezależnymi, stojącymi obok siebie. Ściśle łączą się ze sobą. Uniżenie jest nierozłączną częścią wywyższenia ${ }^{46}$. W tekście potwierdzają to spójniki oı́ („dlatego”) oraz kaí („i”). $\Delta$ ıó wyraża konsekwencję $e^{47}$, tłumaczy wartość

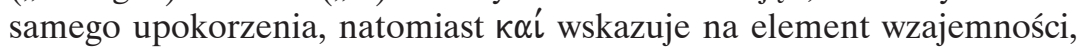
zaznaczając odpowiedź ze strony Ojca ${ }^{48}$. Działanie Boga względem Jezusa

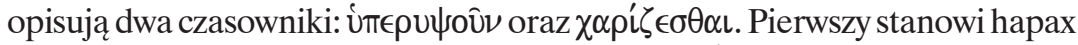

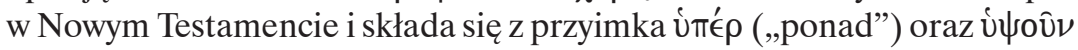
(„wywyższyć”). Połączenie to akcentuje najwyższe z możliwych wywyższenie. Ilustruje też modus agendi Boga objawiony przez Jezusa w Ewangeliach

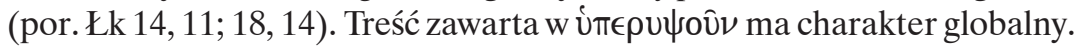
Obejmuje zmartwychwstanie Jezusa, wniebowstąpienie i wyniesienie na

${ }^{41}$ Por. R. Penna, Lettera ai Filippesi, Lettera a Filemone, dz. cyt., 51.

${ }^{42}$ Por. tamże.

${ }^{43}$ Cyceron uważał śmierć krzyżową jako niegodną obywatela wolnego, dlatego twierdził, że sama nazwa krzyż „musi być daleko nie tylko od ciała obywateli rzymskich, lecz także od [ich] myśli, oczu i uszu" - por. R. Fabris, Lettera ai Filippesi, Lettera a Filemone, dz. cyt., 136. Autor powołuje się na Cicero, Pro Rabirio 5, 10, 16. Zachowała się też satyra pochodząca z przełomu pierwszego i drugiego wieku, traktująca o skazaniu na śmierć krzyżową pewnego niewolnika. Kapryśna matrona kazała go ukrzyżować zupełnie za nic, usprawiedliwiając się słowami: „Czyż niewolnik jest człowiekiem? Chociaż nie uczynił niczego, ja tego chcę i nakazuję, moja wola jest racją wystarczającą" - por. R. Penna, Lettera ai Filippesi, Lettera a Filemone, dz. cyt., 51. Autor powołuje się na Giovenale (Juwenalis), Satire 6, 219-223.

${ }^{44}$ Por. M. Hengel, La crucifixion dans l'antiquité et la folie du message de la croix, dz. cyt., 92.

${ }^{45}$ Por. tamże.

${ }^{46}$ Por. J. Ernst, Die Briefe an die Philipper, an Philemon, an die Kolosser, an die Epheser, dz. cyt., 70 .

${ }^{47}$ Por. R. Popowski, $\delta ı$, Wielki słownik grecko-polski Nowego Testamentu, Warszawa 1995, 139.

${ }^{48}$ Por. P. T. O'Brien, The Epistle to the Philippians..., dz. cyt., 233. 
prawicę Boga, mimo iż nie są one wzmiankowane w tekście ${ }^{49}$. Drugi zaś czasownik zawiera w sobie łaskę ( $\chi \alpha$ $\rho \iota \varsigma)$ i oznacza „obdarzyć, uczynić łaskę". Wyraża zatem darmowe działanie Boga na korzyść Jezusa, potwierdza Jego zbawczy czyn ${ }^{50}$. Flp 2, 9 jest jedynym miejscem w Nowym Testamencie, w którym jest mowa o akcie łaski udzielonej Chrystusowi ${ }^{51}$. Dar Boży konkretyzuje się w nadaniu Jezusowi imienia ponad wszelkie imię. Termin ő $\nu \mu \alpha$ (,imię”) jest tłumaczeniem hebrajskiego שִ (szem). W znaczeniu absolutnym zgodnie ze Starym Testamentem wyraża ono Bożą obecnośćc ${ }^{52}$. Nowe imię Jezusa brzmi kúpıos („Pan” - por. w. 11) ${ }^{53}$ i pochodzi

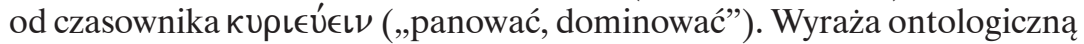
godność oraz funkcję powszechnego panowania ${ }^{54}$. W LXX tytuł kúpıoৎ był odpowiednikiem JHWH (por. Am 5, 8; Ps 68 [67]; 83 [82], 19; Iz 42, 8). Ukrzyżowanemu i wywyższonemu ponad wszystko Chrystusowi została więc przyznana wielkość Boga Izraela ${ }^{55}$.

Kúpıos - jak zauważyliśmy - wyraża uniwersalną władzę i ściśle łączy się z imieniem Jezus, które w wersecie 10 występuje samodzielnie. Tym samym podkreśla historycznego Jezusa, który uniżył się aż do śmierci ${ }^{56}$. Dzięki interwencji Boga otrzymuje homagium od istot niebieskich, ziemskich i podziemnych. Hymn nawiązuje w tym miejscu do Iz 45, 23: „Przede Mną się zegnie wszelkie kolano, wszelki język na Mnie przysięgać będzie”. Kontekst Izajaszowego tekstu dotyczy Boga-Stworzyciela świata, jedynego Pana, który kieruje historią (por. Iz 45, 18. 21-22), i zapowiada uniwersalne homagium narodów. Hołd ten obecnie jest przyznany Jezusowi. Zwrot

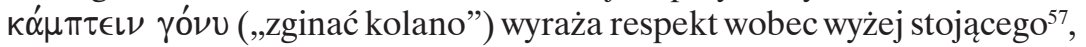
pojawia się w kontekstach modlitwy (por. 1 Krn 29, 20; 2 Krn 29, 29). Często łączy się z czasownikiem $\pi \rho 0 \sigma \kappa \cup \nu \in \hat{\nu}$ („,oddawać pokłon, padać na twarz" $)^{58}$. Jezus jest więc odbiorcą absolutnej czci.

W cytacie Flp 2, 10b-11a tekst Izajaszowy jest rozszerzony o trzy kategorie istnień, które zginają kolano w imię Jezusa. Triada trzech przymiotników

${ }^{49}$ Por. R. Penna, Lettera ai Filippesi, Lettera a Filemone, dz. cyt., 52.

${ }^{50}$ Por. B. Mayer, Philipperbrief/Philemonbrief, dz. cyt., 33; R. Fabris, Lettera ai Filippesi, Lettera a Filemone, dz. cyt., 138.

${ }^{51}$ Por. J. Heriban, Inno cristologico (Flp 2, 6-11), art. cyt., 391.

${ }^{52}$ Por. D. J. MacLeod, Imitating the incarnation of Christ..., art. cyt., 441.

${ }^{53}$ Augustyn i Pelagiusz sugerowali, że tym nowym imieniem Jezusa jest vió (,„Syn”); Cyryl

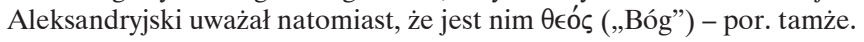

${ }^{54}$ Por. R. Penna, Lettera ai Filippesi, Lettera a Filemone, dz. cyt. 54.

${ }^{55}$ Por. tamże.

${ }^{56}$ Por. R. Fabris, Lettera ai Filippesi, Lettera a Filemone, dz. cyt., 139.

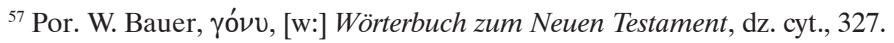

${ }^{58}$ Por. R. Fabris, Lettera ai Filippesi, Lettera a Filemone, dz. cyt., 139, przyp. 80. 


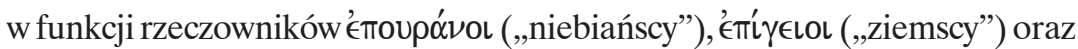

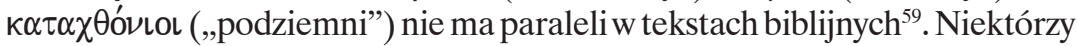
dostrzegają w nich moce i potęgi, które w hellenistycznym świecie panują nad kosmosem, wpływają na los człowieka i są wrogie Bogu. Domagają się uznawania i czci. Ich władza teraz została złamana przez Chrystusa ${ }^{60}$ i muszą uznać Jego panowanie. Inni natomiast interpretują te trzy kategorie istnień jako aniołów (niebiańscy), ludzi (ziemscy) oraz zmarłych (podziemni) i podkreślają, iż całe universum uczestniczy w hołdzie składanym Jezusowi $^{61}$. Ta opinia wydaje się bardziej przekonująca, ponieważ w Flp 2, 10 nie czyni się żadnych aluzji do wrogich mocy. Ponadto bezpośrednie odniesienie do Iz 45, 23 dodatkowo przemawia, by we wspomnianych kategoriach istnień dostrzec powszechny hołd oddawany Jezusowi ${ }^{62}$.

Hymn osiąga swój climax w wyznaniu, że „Panem jest Jezus Chrystus” (w. 11). Cały akcent wersetu 11 spoczywa na imieniu Pan (кúpıos). Zajmuje ono pozycję emfatyczną. "Wszelki język” odnosi się do wszystkich ludów w ich różnorodności etnicznej i kulturowej (por. Iz 66, 18b; Dn 3, 96) ${ }^{63}$.

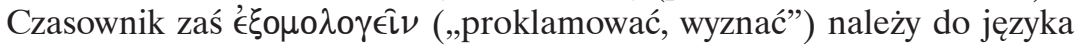
związanego z liturgią, występuje w kontekstach modlitwy, w której się uznaje i wyraża absolutne i jedyne panowanie Boga (por. 1 Krn 16, 4. 34;

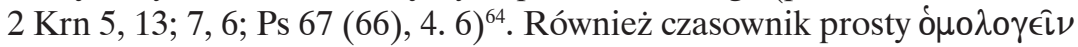
wiąże się z wyznawaniem wiary chrześcijańskiej, która otwarcie obwieszcza, że „Jezus jest Panem” (Rz 10,9). W tradycji żydowskiej nie można było wymawiać imienia Boga ${ }^{65}$. Chrześcijańska wspólnota wprowadziła w tym

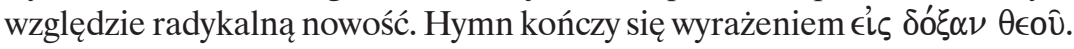
Słowa te odnoszą się bezpośrednio do wywyższenia Jezusa, służą też jako zakończenie całego hymnu w formie doksologii ${ }^{66}$. Jezus Chrystus nie jest zastępcą czy też konkurentem Boga ${ }^{67}$. Jego tożsamość wyraża się w byciu

\footnotetext{
${ }^{59}$ Por. Tamże 140.
}

${ }^{60}$ Por. J. Ernst, Die Briefe an die Philipper, an Philemon, an die Kolosser, an die Epheser, dz. cyt., 71; J. Gnilka, Der Philipperbrief/Der Philemonbrief, dz. cyt., 128.

${ }^{61}$ Por. R. Fabris, Lettera ai Filippesi, Lettera a Filemone, dz. cyt., 140; P. T. O’Brien, The Epistle to the Philippians..., dz. cyt. 234; G. Barbaglio, La Teologia di Paolo, dz. cyt., 362.

${ }^{62}$ Por. J. Heriban, Inno cristologico (Flp 2, 6-11), art. cyt., 392.

${ }^{63}$ Por. R. Fabris, Lettera ai Filippesi, Lettera a Filemone, dz. cyt., 141.

${ }^{64}$ Por. tamże.

${ }^{65}$ We wspólnocie z Qumran była zabroniona przysięga nawet na alef i lamed ( $E l$ - „Bóg” oraz Adonaj - „Pan”). Kto zaś przysięgał, profanował Imię - por. R. Fabris, Lettera ai Filippesi, Lettera a Filemone, dz. cyt., 141, przyp. 86. Autor powołuje się na 1 QS XV, 1. 3.

${ }^{66}$ Por. J. Heriban, Inno cristologico (Flp 2, 6-11), art. cyt., 393.

${ }^{67}$ Por. tamże. 
„na chwałę Boga Ojca”68. Jako wywyższony Pan zachowuje również swą postawę pokory. W ten sposób ukazuje się eklezjalnej wspólnocie jako wzór w dwóch etapach swego doświadczenia ${ }^{69}$. Jego Osoba jest najskuteczniejszą parenezą dla wiernych.

\section{Podsumowanie}

Flp 2, 6-11 w poetycki sposób opisuje paradoksalną drogę Jezusa Chrystusa. Będąc na równi z Bogiem, wszedł w historię ludzką bez żadnych przywilejów, utożsamił się z każdym z ludzi. Dobrowolnie doświadczył absolutnego bez-znaczenia. Uczynił się zależnym od człowieka. Przeżył ekstremalne poniżenie. Bóg potwierdził Jego drogę, wywyższając Go ponad wszystko i obdarzając godnością Kyriosa, któremu składa hołd całe stworzenie. Hymn jest doskonałą parenezą. Zachęca chrześcijan, by kroczyli szlakiem wyznaczonym przez Chrystusa i dobrowolnie rezygnowali z walki o osobisty honor, własne prawa i zasługi. Proponuje samozaparcie, ofiarę z siebie i wyrzeczenie. Droga bowiem do góry wiedzie zawsze przez drogę w dół.

Kraków

STANISEAW WITKOWSKI MS

\section{Słowa kluczowe}

Jezus Chrystus, ogołocenie, poniżenie, ofiara z samego siebie, śmierć na krzyżu, wywyższenie, chwała, imię, Pan

\section{Summary}

\section{Humbled and Raised Christ (Ph 2, 6-11)}

$\mathrm{Ph} 2,6-11$ in a poetic way describes the paradoxical way of Jesus Christ. Being equal with God, He entered human history with no privileges and identified Himself with every human being. Of His own free will, He experienced complete insignificance. He subordinated himself to man. He survived extreme humiliation. God confirmed His way by raising Him above all and bestowing upon him the dignity of Kyrios, to whom all creation pay homage. This hymn is perfect paranesis. It encourages Christians to follow the way marked by Christ and to resign voluntarily from the battle for personal reputation, laws and merits. It proposes persistence, self-sacrifice and renunciation. To ascend highly one must descend.

\section{Keywords}

Emptying, humiliation, self-sacrifice, death on a cross, Jesus Christ, exaltation, glory, name, Lord

${ }^{68}$ R. Fabris, Lettera ai Filippesi, Lettera a Filemone, dz. cyt., 142.

${ }^{69}$ Por. J. Heriban, Inno cristologico (Flp 2, 6-11), art. cyt., 392. 